placed in charge of frontier surveys in India, and after taking command of the Survey Service in Mesopotamia during 1917-18, he succeeded Sir Sidney Burrard in the latter year as surveyor general of India, retiring from that post in 1924 .

Ryder's greatest contributions to geography were in the field of survey and exploration in China and Tibet. In 1895, not long after joining the Survey of India, he served on the Mekong Boundary Commission, demarcating the Burma-Indo-China frontier. During 1898-1900, with Major Davies, he surveyed. most of the routes in the Yunnan Province of China and in parts of Szechwan. Their journeys ended in a voyage down the Yangtse River to Shanghai, and their work forms the basis of present-day maps of these regions. In 1901-2 he was again in China as a survey officer with the Chinese Expeditionary Force. After a brief interval in India, he joined the Tibet Frontier Commission in 1903 and Sir Francis Younghusband's mission to Lhasa (1904). Taking advantage of the newly imposed treaty terms and of the presence of British troops, Ryder was given a free hand to carry out exploration in southern Tibet, and accompanied by Captain Rawling and a very small party he travelled westwards up the Tsangpo valley, exploring and surveying many thousands of square miles of, for the most part, unknown country. They fixed the sources of the Tsangpo, Sutlej and Indus, surveyed Lakes Manasarowar and Rakas Tal, and the region of the holy mountain of Kailas. Their work was controlled by the positions of the Himalayan snow peaks to the south which had been fixed many years previously from the plains of India. A great number of additional peaks were fixed, and the claim that Mount Everest was the highest mountain, in any event in regions hitherto explored, remained unassailed. The expedition reached Simla by way of the Shipki Pass in January 1905; its results form by far the greatest single addition to knowledge of the topography of the Tibetan plateau.

In 1913-14 Ryder served as chief survey officer on the Turco-Persian Boundary Commission, and as deputy commissioner during the absence of $\mathrm{Mr}$. Wratislaw in the later months. The demarcation of this long frontier was complicated by a number of intricate negotiations. For his explorations in China and Tibet Ryder received the Patron's Gold Medal of the Royal Geographical Society, the Silver Medal of the Royal Scottish Geographical Society, and the Gold Medal of the French Geographical Society, and he was awarded the C.I.E. for his work on the TurcoPersian boundary.

C. G. LEWIS.

\section{Dr. Catherine Alice Raisin}

Dr. Catherrne Alice RaIsin, a pioneer who blazed many new trails, died at Cheltenham on July 13 at the age of ninety. Her early education was received at the North London Collegiate School, of which she always spoke with gratitude as being one of the earliest schools to start providing more serious education for girls. Miss Raisin continued as a teacher at her old school until 1875, when the opening of certain classes to women students was advertised by University College, London. Among these was a course in geology by Prof. Morris. Miss Raisin attended this class, and so became the first woman to take geology in the University. In the following year she joined Prof. Morris' classes in mineralogy, only to discover after the course was completed that it had not been officially open to women.

In 1878 the degrees of the University of London were thrown open to women, and Miss Raisin at once began to prepare for her B.Sc. After passing the Intermediate Science examination in 1879, she selected geology, botany and zoology as her three subjects. She attended Prof. Bonney's classes in geology at University College during 1880-82, and Prof. Bower's classes in botany. Attracted by Prof. Huxley's work in zoology, Miss Raisin obtained special permission from him, in 1883 , to attend his classes at the Royal School of Mines. After graduating B.Se. with honours in geology in 1884, Miss Raisin continued at University College as a research worker, and at the same time as a voluntary assistant to Prof. Bonney, who was then very much overburdened with work. She received her D.Sc. in 1898, and in 1902 was elected a fellow of University College.

During the years when she was preparing for her degree, Miss Raisin achieved one of her earliest ambitions by founding and organizing a discussion club for women-the Somerville Club-which foreshadowed the youth movement of to-day. The work involved must have seriously interrupted her studies, for when the Club opened in 1880 she had already enrolled a thousand members. Under her inspiring leadership, first as honorary secretary and later as chairman, the Club flourished actively for several years. Meanwhile, other educational amenities for women were being developed in London, and in 1887, having served its initial purpose, the Club was wound up.

During 1886-90, Dr. Raisin was demonstrator in botany at Bedford College for Women. In 1890 she succeoded Prof. Grenville A. J. Cole as head of the Geology Department at Bedford College, a position which she held, together with the headship of the Geography Department, until she retired in 1920. Her outstanding teaching and administrative ability are further evidenced by the facts that she was head of the Botany Department during 1891-1908 and was also vice-principal of the College during 18981901. From these additional duties she eventually resigned in order to give more time to the claims of geology.

The originality of Dr. Raisin's teaching was in no respect better shown than in her celebrated lectures on petrographic provinces, which became the more fascinating since they were illustrated by practical work on rock specimens of her own collecting from many of the classic areas of Europe and North America. She was a first-class petrographer, with a firm grasp of the optical properties of minerals-then quite exceptional. Rightly unbound by fashion in petrogenetic thought, as time has shown, she stood almost alone in Britain in stressing the work of Lacroix, Termier and Sederholm on granitization, even at the time when crystal differentiation was beginning to hold the field as a major petrogenetic process.

Dr. Raisin's published work includes a long series of petrological and stratigraphical studies, dealing with rocks from the British Isles, Europe, North Africa and India. Her first paper, concerned with the metamorphic rocks of South Devon, was published in 1887, and is notable as representing an early attempt to recognize and map metamorphic facies. Dr. Raisin is, however, best known for her detailed investigation of serpentines.

In 1893 Dr. Raisin was awarded the Lyell Fund by 
the Geological Society of London, being the first woman to receive any such recognition from this Society. At that time women were not even allowed to attend meetings of the Society, and Prof. Bonney received the award on her behalf. When in 1919 women were admitted as candidates for fellowship of the Geological Society, Dr. Raisin was elected a fellow.

Dr. Raisin will be remembered by her students, not only as a stimulating and enthusiastic teacher, who worked ungrudgingly to promote their interests, but also as a generous, brave and sympathetic woman whom they loved.

\section{Doris L. Reynolds.}

\section{Prof. H. E. Annett, M.B.E.}

THe death occurred on April 11, 1945, of Henry Edward Annett, at the age of seventy-four years. Dr. Annett's scientific career was varied and his interests ranged over several fields-tropical diseases, bacteriology and pathology among them.

As an undergraduate at the University of Liverpool, Dr. Annett studied physics under Sir Oliver Lodge, but later, in spite of Lodge's persuasions to continue his work as a physicist, he decided to study medicine. After graduating in medicine, he was elected to an 1851 Exhibition and carried out research on tuberculosis under Robert Koch in Berlin. $\mathrm{He}$ was a member of the first malaria expedition sent to West Africa by the Liverpool School of Tropical Medicine in 1891, and during the following year he himself directed a similar expedition. In 1905 he led the Animal Disease Expedition to Uruguay, and in 1906 the Colonial Office Expedition to the West Indies. He was later appointed to the chair of comparative pathology at the University of Liverpool, an appointment which he held until 1911.

Dr. Annett then devoted himself to research in bacteriology, a field in which he became widely known, and for some years was director of the Bacteriological Research Department of Messrs. Evans, Lescher and Webb, in Runcorm. While there, he discovered the 'Liverpool' virus used for killing rats and mice. During the War of 1914-18 he was asked to study the effect on child health of milk preservation by the use of formaldehyde and the conclusions he reached, which were embodied in a Select Committee report, led to a legal ban on formol preservation. For this service he was awarded the M.B.E. The later years of his life were devoted exclusively to researches on cancer and allied problems, and he was occupied with this work up to the time of his death.

Dr. Annett's health had been declining for some years, and his unfailing kindness and encouragement, graced with a rare sense of humour, will be missed by those younger research workers who had the good fortune to come into contact with him.

\section{SARAF Barnes.}

\section{Dr. W. Knoche}

DR. WALter KNoche, a well-known investigator on climatology, atmospheric electricity, geography and ethnology, died on July 3 at Buenos Aires. He was climatologist to the Servicio Meteorologico Nacional of the Argentine Republic, as a successor to the late Robert Mossman.

Knoche was born in Berlin on March 7, 1881, his mother being a sister of Paul Ehrlich, one of the pioneers of modern chemical therapeutics. Through his uncle's example, Knoche received a powerful stimulus towards medical and physiological problems, and indeed a great number of his climatological investigations were devoted to the relations between climate and man, animals and plants. He studied at Geneva and Berlin, as a pupil of von Richthofen in geography and von Bezold in meteorology. After a short scientific expedition to Bolivia, where he made an extensive series of valuable meteorological observations at the height of 5,200 metres, he became in 1910 the chief of the Meteorological and Geophysical Institute of Chile, a post which he held until 1916. A great number of his early publications deal with atmospheric electricity, based on his own observations on land and sea and on mountains throughout the vast area between Teneriffe and Easter Island, and especially South America. His expedition, in 1911, to Easter Island led him to begin a comprehensive study of its different geographical and anthropological problems, which he discussed in a valuable monograph.

During recent years, Knoche's chief interest was concentrated on phytoclimatology, the formation of deserts, colonization, classification of climates and general bioclimatology, and it is fair to consider him one of the pioneers of this new branch of science. He was the author, together with the late Vladimir Borzakov, of a book on the climate of Argentina, now in the press.

A more detailed review of Knoche's many publications, considerably more than two hundred in number and dealing with an unusually wide range of subjects, will be given in the Argentine journal Ciencia e Investigación.

OTTO SCHNEIDER.

\section{Prof. F. von Wettstein}

THERE will be general regret at the information, received from private sources, that Prof. Fritz von Wettstein has died recently in Germany.

Son of Prof. R. V. Wettstein, of the University of Vienna, he achieved as great an eminence as his father in the advancement of botanical and genetical science. Under Erwin Baur at the Kaiser Wilhelm Institut, Berlin-Dahlem, he undertook research work on hybrids and polyploids in mosses, and was one of the first to show the relationships and characteristics of polyploid forms. In 1926 he was appointed professor of botany in the University of Göttingen, where his energies built up the Botanical Garden to be a centre for the breeding of cacti and for investigations on various cryptogams. In 1933 he was appointed to one of the premier botanical chairs of Germany, that of the University of Munich; and later, on the death of Erwin Baur, he was called to take charge, I believe unwillingly, of the German plant breeding and botanical programmes that were under way at the Kaiser Wilhelm Institut at Berlin-Dahlem.

Of a quiet unassuming character, earnest and extremely enthusiastic on any subject relating to botanical genetics, his death, at a comparatively early age (about fifty-eight), is a great loss to science. What I remember most distinctly about Wettstein was his extreme friendliness and overwhelming hospitality to all with whom he came in contact; and despite a lack of English, his ability to overcome language difficulties when talking about his well-loved Funaria hygrometrica and Solanum chimæras.

F. W. Sansome. 